\title{
Structure and Distribution of Macrobenthos Community in Code River, Yogyakarta, Indonesia
}

\author{
Putri Latifa Arumsari ${ }^{\text {a }}$ and Ratih Ida Adharini ${ }^{\text {a* }}$ \\ ${ }^{\text {a }}$ Department of Fisheries, Faculty of Agriculture, Universitas Gadjah Mada \\ J1. Flora 1A Bulaksumur Yogyakarta \\ *E-mail: ratih.adharini@ugm.ac.id
}

\begin{abstract}
This research aimed to explore the community structure of macrobenthos in Code River, Yogyakarta. This research was conducted during December 2019-January 2020 in Code River, Yogyakarta. Data was taken 4 times in 6 stations. Macrobenthos was taken using a Surber net with a size of $30 \times 30 \mathrm{~cm}$ and sampling at 5 spots in each station. Data analysis consisted of density, diversity index, dominance index, and evenness index. Water quality data consisted of water temperature, flow velocity, water depth, water $\mathrm{pH}$, dissolved oxygen, and organic matter. The results showed that the density of macrobenthos ranged from 54-172 ind $/ \mathrm{m}^{2}$. Our results showed that Code River has moderate diversity based on the ShannonWiener diversity index. Sulcospira testudinaria is the most dominant species in Code River. The evenness index showed high except at station 2 which was categorized as moderate. Code River has pretty good water quality, but stations 3,4 , and 5 which are located in the city area, it has a high organic matter content.
\end{abstract}

Keywords: abundance, organic compound, diversity, dominance, macrobenthos

\section{INTRODUCTION}

Code River is located in Yogyakarta Province in Indonesia ( $\left.7^{\circ} 51^{\prime} 05.1^{\prime \prime} \mathrm{S} 110^{\circ} 24^{\prime} 09.1^{\prime \prime E}\right)$, which has upstream at the foothills of Mount Merapi and the Opak area as downstream. The Code River crosses three districts in Yogyakarta which are densely populated with all its activities. Human activities affect river ecosystems such as changes in land use and modification of water resources that change the physical, chemical, and biological characteristics of the river ecosystems. Kiesel et al. (2019) also stated that river ecosystems are affected by global climate change, pollution, economy, human migration, and biota from outside the habitat. The high stress on river ecosystems due to the dynamics of current causes a significant increase in biomass, as well as reduced abundance and density of organisms (Sabater et al., 2018).

Macrobenthos are organisms that live attached to the substrate and in the sediment bed of the waters with a size of more than $2 \mathrm{~mm}$ (Borisov et al., 2016). Benthic animals have a role in the food chain as first and second consumers, or as food sources from higher trophic levels. Macrozoobenthos are deposit feeders (accumulators) and filter feeders (filters) (Ulfa et al., 2018). Macrobenthos inhabits a variety of substrates including mud, sand, sandstone, rocks, and rock edges (Abd Allah et al., 2018). Based on Peng et al. (2013), macrobenthos has an important position in ecosystems such as nutrient turnover, 
pollutant metabolism, and secondary producers in marine sediments. The composition of the benthic macroinvertebrate family is used as an indicator of water quality because it is sensitive to water pollution (Zawiejska et al., 2012). Changes in the structure of the macrobenthos community have a good correlation with environmental factors. Macrobenthos can be used as bioindicators for monitoring and assessing the aquatic environment in river, sea, and lake ecosystems (Chen et al., 2018).

The limited movement of macrobenthos can be used to respond to environmental changes. The macrobenthos compositions that can be observed include species, diversity, abundance, and biomass (Chen et al., 2018). The abundance of macrobenthos is influenced by factors such as temperature, salinity, dissolved oxygen, sediment, and organic matter and no single factor can be considered as the main factor because these factors influence each other (Pawar \& Al-Tawaha, 2017; Peng et al., 2013). Based on Noman et al. (2019), the abundance and distribution of macrobenthos depend on depth, tides, water flow, and nutrients. The species composition and density of macrobenthos change based on variations in water temperature, dissolved oxygen, depth, water flow, substrate quality, and mud. Macrobenthos density is also influenced by the availability of food resources (Weerman et al., 2011). This study aims to study the community composition of macrobenthos in the Code river and its relationship with water quality parameters.

\section{METHODS}

The research was conducted from December 2019 to January 2020 at the Code River, Yogyakarta. The study was divided into 6 stations that crossed the upstream, middle, and downstream parts by purposive sampling. Sampling was carried out every two weeks in the morning for 8 weeks.

\section{Collection Samples}

Macrobenthos were collected from 6 stations with 5 sampling points and taken using a $30 \times 30$ $\mathrm{cm}$ Surber net. The surfer net is placed and stretched on the bottom of the water with the net opening against the water current. The substrate in the surfer plot is stirred so that the macrobenthos leaves the substrate and enters the net bag. The attached macrobenthos was taken and preserved with $4 \%$ formalin. Macrobenthos identification was carried out at the Aquatic Ecology SubLaboratory of the Department of Fisheries UGM using the macrobenthos identification book of Freshwater Invertebrates of United States $2^{\text {nd }} \mathrm{Ed}$.

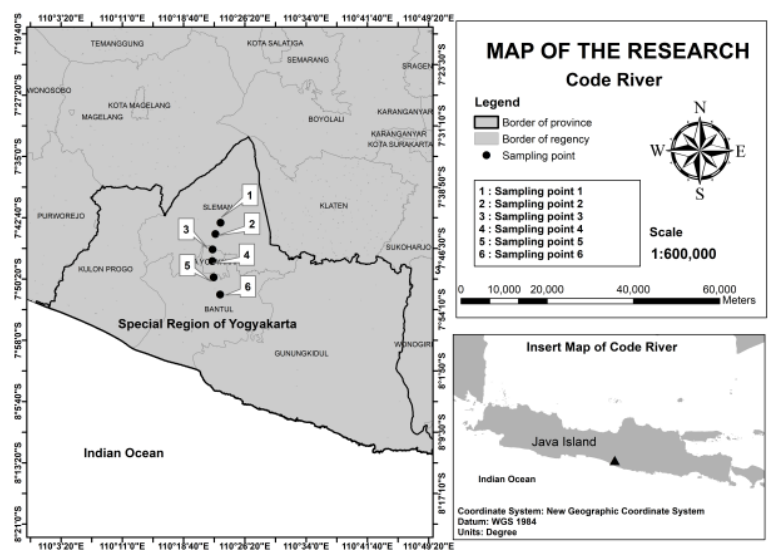

Figure 1. Sampling sites of macrobenthos in Code River, Yogyakarta

\section{Water Quality Parameters}

Physical and chemical parameters serve as supporting data to strengthen the status of water quality including water temperature, current velocity, water depth, substrate type, $\mathrm{pH}, \mathrm{DO}$ (Dissolved Oxygen), and an organic compound. Measurement of current velocity by the floating method and water depth was measured using a roll meter. Determination of the type of substrate by direct observation. Water temperature, $\mathrm{pH}$, and DO (Dissolved Oxygen) are measured by Water Quality Checker (WQC AZ 86031), organic compounds were measured by titrimetric method.

\section{Data Analysis}

Macrobenthos density index was calculated by Welch (1948) using the following formula:

$$
K_{i}=\frac{10000}{B \times n} \times a
$$

Where $K i$ is density index (ind $/ \mathrm{m}^{2}$ ), 10000 is a conversion from $\mathrm{cm}^{2}$ to $\mathrm{m}^{2}, B$ is surber net area, $n$ is Number of sampling points, $a$ is the number of macrobenthos individuals obtained.

Macrobenthos diversity can be calculated using the Shannon and Wiener diversity index by 
Wilhm \& Dorris (1966) using the following formula:

$$
H^{\prime}=-\sum\left(\frac{n i}{N}\right) \ln \left(\frac{n i}{N}\right)
$$

Where $H^{\prime}$ is the diversity index by ShannonWiener, $n i$ is the number of individuals of each species, $N$ is the total number of individuals.

The Shanon-Wiener diversity index value category has a certain range of values, namely: $\mathrm{H}^{\prime}<1$ : Low diversity; $1 \leq \mathrm{H}^{\prime} \leq 3$ : Moderate diversity; and $\mathrm{H}^{\prime}>3$ : High diversity.

The dominance of macrobenthos was carried out to analyze the dominance of certain species based on the Simpson Dominance Index by Litaay et al. (2017) with the following formula:

$$
\mathrm{C}=\sum\left(\frac{n i}{N}\right)^{2}
$$

Where $C$ is Simpson dominance index, $n i$ is the number of individuals of each species, $N$ is the total number of individuals.

The Simpson dominance index value category has a certain range of values, namely: $0<\mathrm{D} \leq 0.3$ : Low dominance; $0.3<\mathrm{D} \leq 0.6$ : Moderate dominance; and $0.6<\mathrm{D} \leq 1$ : High dominance.

The evenness index of the Shannon-Wienner macrobenthos was calculated by Asriani et al. (2019) using the following formula:

$$
\mathrm{E}=\frac{H^{\prime}}{\ln (S)}
$$

Where $E$ is the Evenness index, $H^{\prime}$ is the ShannonWiener diversity index, and $S$ is the number of species.

The Shannon-Wienner evenness index (E) indicates the distribution of individuals in given environment/habitat. $E$ close to $0=$ the distribution of individuals between species is uneven/there are certain dominant species; $\mathrm{E}$ is close to $1=$ the distribution of individuals between species is even.

\section{RESULTS AND DISCUSSION}

Macrobenthos in the Code River Yogyakarta has various types and numbers at each station from upstream to downstream. The abundance of macrobenthos in Code River is presented in Figure
2, while the diversity, dominance, and evenness index are presented in Table 1.

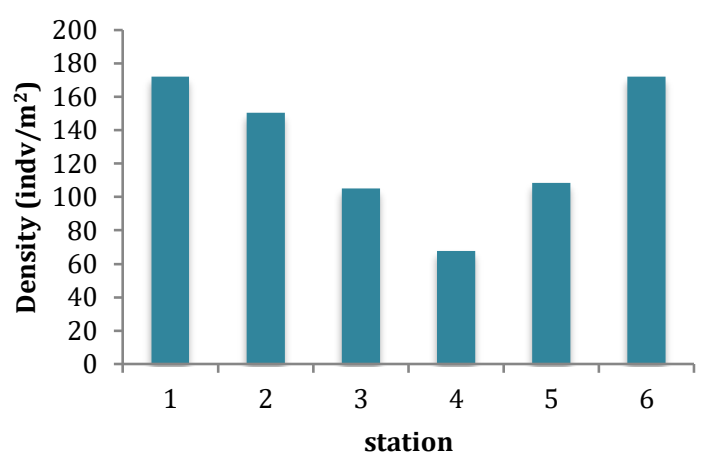

Figure 2. The abundance of macrobenthos in the Code river

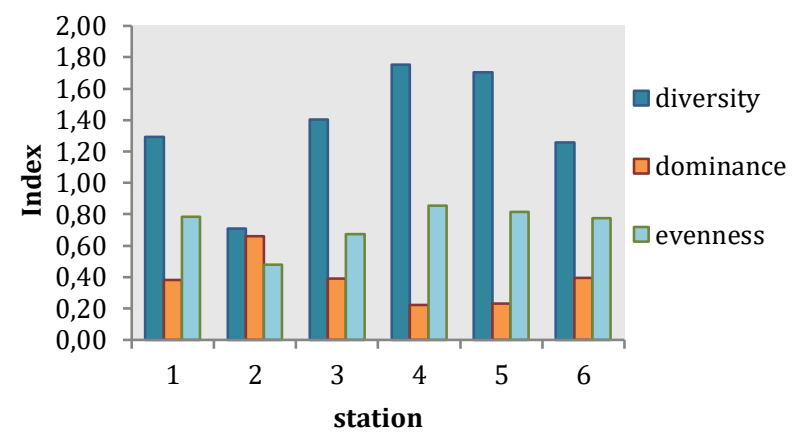

Figure 3. The diversity, dominance, and evenness index of macrobenthos in Code river

The density of macrobenthos shows that from upstream to downstream, the density of macrobenthos becomes lower. The macrobenthos dominance index showed fluctuated. The diversity of macrobenthos is categorized as low to moderate. The index of dominance and diversity is inversely proportional, the higher the diversity, the lower the dominance of macrobenthos. The evenness index is categorized as moderate to high.

Water quality parameters include physical and chemical parameters. Physical parameters include water temperature, current speed, and depth. Chemical parameters include Dissolved Oxygen, $\mathrm{pH}$, and Organic compound. Water quality parameters of Code River in each station can be seen in Table 1.

Table 1 . Water quality parameters 


\begin{tabular}{lcccccc}
\hline Parame & \multicolumn{6}{c}{ Station } \\
\cline { 2 - 7 } ters & $\mathbf{1}$ & $\mathbf{2}$ & $\mathbf{3}$ & $\mathbf{4}$ & $\mathbf{5}$ & $\mathbf{6}$ \\
\hline $\begin{array}{l}\text { Substrate } \\
\text { Wacky }\end{array}$ & $\begin{array}{l}\text { rocky } \\
\text { sand }\end{array}$ & $\begin{array}{l}\text { rocky } \\
\text { mud }\end{array}$ & mud & $\begin{array}{l}\text { rocky } \\
\text { mud }\end{array}$ & $\begin{array}{l}\text { rocky } \\
\text { sand }\end{array}$ \\
$\begin{array}{l}\text { Water } \\
\text { temp. } \\
\left({ }^{\circ} \mathrm{C}\right)\end{array}$ & 27.59 & 27.53 & 27.64 & 28.61 & 29.26 & 29.02 \\
$\begin{array}{l}\text { Current } \\
\text { speed } \\
(\mathrm{m} / \mathrm{s})\end{array}$ & 0.44 & 0.48 & 0.59 & 0.38 & 0.43 & 0.38 \\
$\begin{array}{l}\text { Depth } \\
(\mathrm{m})\end{array}$ & 0.22 & 0.27 & 0.23 & 0.23 & 0.27 & 0.21 \\
$\begin{array}{l}\text { DO } \\
(\mathrm{ppm})\end{array}$ & 5.01 & 5.72 & 5.35 & 4.26 & 4.07 & 3.56 \\
$\begin{array}{l}\text { pH } \\
\text { Organic } \\
\text { matter } \\
(\mathrm{ppm})\end{array}$ & 10.60 & 9.17 & 11.86 & 18.66 & 22.30 & 10.60 \\
\hline
\end{tabular}

The highest abundance of macrobenthos was found at 172 individuals $/ \mathrm{m}^{2}$. The most common species found at station 1 was Sulcospira testudinaria which is commonly found in Java and Sumatra Islands (Mustika et al., 2019). According to Marwoto \& Isnaningsih (2012), S. testudinaria has a wide distribution in Java Island and is tolerant to polluted water. Its habitat is in fastflowing water such as rivers or rocky streams. The results show that the number of individuals of each species was high at station 1 even though the dominance was moderate. The location of the station is near fishery and rice fields and is characterized by sloppy topography with a fairly large river width. The river channel at station 1 has been modified by humans in which the river bank has been modified with concrete structure. The condition of the river is overgrown with riparian plants and large rocks that can be used by macrobenthos for shelter. Moreover, relatively high DO and low organic matter at station 1 is favorable for macrobenthos organisms. The dissolved oxygen content has a positive correlation with the abundance of macrobenthos (Figure 4). This finding was correlated with a high abundance of macrobenthos at station 1 .

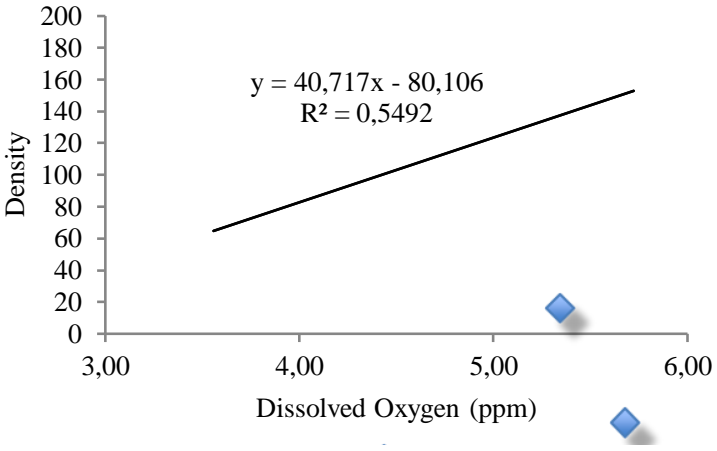

Figure 4. The correlation of organic matter and density of macrobenthos.

Station 2 has an abundance value of 150.56 individuals $/ \mathrm{m}^{2}$. The dominance index of station 2 is the highest with the lowest diversity and evenness index than the other stations. The condition of station 2 shows low species diversity due to the dominance of one species, even though the distribution of the number of individuals for each species is categorized as moderate. The location of station 2 is a sand and stone mining area, so the vegetation around the river is low in density. Sand mining causes changes in river banks and depths. These human activities affect the existence of producers as food sources so that station 2 has low diversity and dominance. Station 2 has a rocky substrate and lots of rocks blocking the river, therefore the organic matter is the lowest.

Station 3 has an abundance value of 105 individuals $/ \mathrm{m}^{2}$; diversity index of 1.41 (medium); dominance index of 0.39 (medium); and an evenness index of 0.67 (high). Station 3 shows the distribution of the number of individuals of each species is high even though the dominance is moderate. Station 3 is located near hotels, hospitals, and people's homes. Station 3 has a rocky mud substrate. The most common types of macrobenthos found at this station are mollusks and arthropods. The abundance of arthropods is because they like rocky substrates (Marmita, 2013, as cited in Nangin et al., 2015). The most common species found at station 3 was Hydropsyche sp. According to Tszydel et al. (2015), larvae of Hydropsyche sp. have a high level of tolerance for water contaminated by municipal and domestic sewage. Hydropsyche angustipennis can accumulate several heavy metals from polluted water. This is also supported by the presence of organic matter which is quite high at station 3 of $11.86 \mathrm{ppm}$. 
Station 4 has an abundance value of 67 individuals $/ \mathrm{m}^{2}$. The highest diversity of macrobenthos at station 4 was 1.75 in the medium category. Station 4 has the lowest dominance of 0.22 which is included in the category of low dominance index. Station conditions showed moderate diversity and high distribution of individual numbers so that no individual dominated. The most common types of macrobenthos found at this station are annelids and mollusks. The annelids found included Tubifex sp., Erpobdella punctate, Placobdella hollensis, and Lumbricus sp. Station 4 has a muddy substrate with an organic matter content of $18.66 \mathrm{ppm}$. River conditions at station 4 have high turbidity and are close to the sewage outlet. The high organic matter content at station 4 supports the higher diversity of macrobenthos at this station compared to other stations. Tubificidae can live in river water with high organic matter, high turbidity, muddy and low dissolved oxygen concentration.

Station 5 has an abundance value of 108 individuals $/ \mathrm{m}^{2} ;$ diversity index of 1.70 (moderate); dominance index of 0.23 (low); and an evenness index of 0.82 (high). Station 5 shows the distribution of the number of individuals for each species is high and no dominant macrobenthos species. This condition indicates that the environment of station 5 has a wide range to be inhabited by various types of macrobenthos so that there is no dominance. Station 5 substrate is rocky mud. The most common types of macrobenthos found at this station are annelids and mollusks. The annelids found at station 5 were the most abundant than the other stations and the most species found was Tubifex sp. Tubificidae can live in river water with high organic matter. This is supported by the condition of organic matter at station 5 which is the highest among other stations, which is $22.30 \mathrm{ppm}$. The muddy substrate conditions are also suitable for the life of Tubifex sp. Dissolved oxygen concentration at station 5 is lower than other stations at $4.07 \mathrm{ppm}$. However, Tubifex sp. can live in conditions of low dissolved oxygen (Sharma \& Chowdhary, 2011; Siahaan et al., 2012).

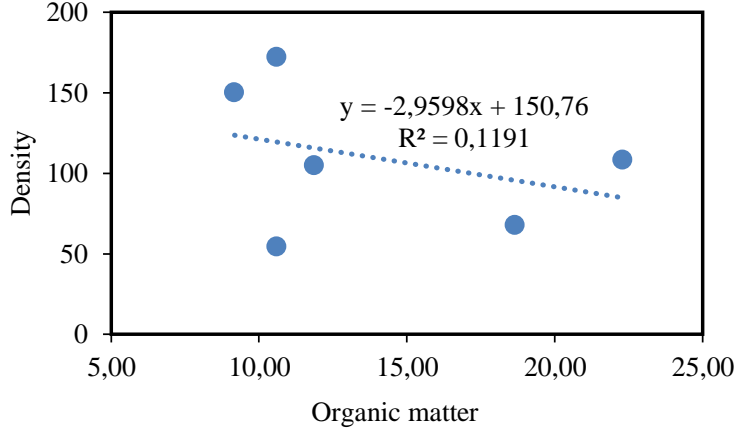

Figure 5. The correlation of organic matter and density of macrobenthos.

The station that has the lowest abundance value is station 6, which is 54 individuals $/ \mathrm{m}^{2}$. The diversity index of station 6 of 1.26 is in the medium category. The dominance index with a value of 0.40 is in the medium category. Station 6 has a rocky sand substrate. The most common taxa are mollusks and annelids. Station 6 is near the aquaculture area and rice fields. The abundance of macrobenthos at station 6 is the lowest because it is located downstream so that a lot of organic material has accumulated at this station from the previous station. Organic matter has a negative correlation with the abundance of macrobenthos (Figure 5). Organic matter station 6 is $10.60 \mathrm{ppm}$ and dissolved oxygen is $3.56 \mathrm{ppm}$. Pollutants in the water can reduce oxygen levels. Sources of polluted materials can be in the form of animal and human waste, garbage, and household and industrial waste. The accumulation of these pollutants reduces the dissolved oxygen content even more so that the dissolved oxygen value of station 6 is lower than the other stations (Putra et al., 2014).

A total of 28 species of macrobenthos were identified from Code River with a total abundance of 658 individuals $/ \mathrm{m}^{2}$. The density of macrobenthos tended to decrease from upstream to downstream which could be due to declining water quality conditions. Code River passes through highly urbanized areas which have a significant impact on water quality, thus affecting the presence of macrobenthos. The results of the diversity index and dominance of the Code River are mostly in the medium category with the highest evenness index being the high category. The value of diversity and dominance in the Code River is inversely proportional. The increase of dominance index will be in tandem with the 
decrease of diversity index due to the capability of benthic macroinvertebrates to respond to the disturbance from the environment (Sharma et al., 2011). In addition, the research conditions were at the beginning of the rainy season so that the abundance and diversity of macrobenthos fluctuated. The increase in rainfall affects the river flow more strongly so that macrobenthos is drifted away by the current. High current velocities can wash away macrobenthos that are not firmly attached to the rock (Pawar \& Al-Tawaha, 2017; Siahaan et al., 2012). The rainy season affected some benthic macroinvertebrates found in lower abundance compared to the dry season. Some macrobenthos is hiding behind rocks to withstand the current. Gastropod was the most commonly found during the rainy season meanwhile, some Arthropods will be drifted under strong current conditions otherwise they stick under the rocks. Variation of the bottom substrates probably controls the macrobenthos.

\section{CONCLUSION}

Our study revealed that the macrobenthos community in Code River was at moderate diversity as shown by Shannon-Wiener index ranged from $0.71-1.75$. The community structure of macrobenthos in Code River was characterized by the abundance of Sulcospira testudinaria, and was influenced by water quality and the type of substrate. Dissolved Oxygen content has a positive correlation with the density of macrobenthos, while organic content has a negative correlation with the density of macrobenthos.

\section{ACKNOWLEDGEMENTS}

We would like to acknowledge the Faculty of Agriculture, Universitas Gadjah Mada for financial support, and R.D. Harimurti and Murwani for technical assistance during the study.

\section{REFERENCES}

Abd Allah AT, Sumaili IA, Gathmy MY, and Awaf BA. 2018. Spatial distribution of marine invertebrates as bioindicator of water quality at intertidal zone OMLI 2021 of sandy shore habitat. Life Science Journal, $15(1), 51-55$.

Asriani N, Ambo-Rappe R, Lanuru M, and Williams SL. 2019. Macrozoobenthos community structure in restored seagrass, natural seagrass and seagrassless areas around Badi Island, Indonesia. Earth and Environmental science, 253(2019), 17.

Borisov RR, Chertoprud ES, and Kovacheva NP. 2016. Water quality assessment in reservoirs: comparative analysis of bioindication systems based on macrobenthos characteristics. Water Resources, 43(5), 818-827.

Chen J, Hu D, Zhang C, and Ding Z. 2018. Temporal and spatial changes of macrobenthos community in the regions frequently occurring black water aggregation in Lake Taihu. Scientific Reports, $8(1), 1-13$

Kiesel J, Guse B, and Bormann H. 2019. Projecting the consequences of climate change on river ecosystems in Multiple Stressors in River Ecosystems. Elsevier, 281-301.

Litaay M, Deviana M, and Priosambodo D. 2017. Biodiversity and distribution of gastropods at seagrass meadow of Balangdatu waters Tanakeke Island South Sulawesi Indonesia. International Journal of Applied Biology, 1(2), 67-75.

Marwoto RM and Isnaningsih NR. 2012. The freshwater snail genus Sulcospira Troschel, 1857 from Java, with description of a new species from Tasikmalaya, West Java, Indonesia (Mollusca: Gastropoda: Pachychilidae). Raffles Bulletin of Zoology, 60(1), 1-10.

Mustika R, Karyadi B, and Singkam AR. 2019. Keragaman dan Kelimpahan Makroinvertebrata di Sungai Sengaur Bengkulu Tengah. Prosiding Semirata BKS PTN Wilayah Barat Bidang MIPA.

Nangin SR, Langoy ML, and Katili DY. 2015. Makrozoobentos sebagai indikator biologis dalam menentukan kualitas air Sungai Suhuyon Sulawesi Utara. Jurnal MIPA, 4(2), 165-168.

Noman MA, Mamunur R, Islam MS, and Hossain MB. 2019. Spatial and seasonal distribution of intertidal macrobenthos with their biomass and functional feeding guilds in the Naf River estuary, Bangladesh. Journal of Oceanology and Limnology, 37(3): 1010-1023.

Pawar PR and Al-Tawaha ARMS. 2017. Population density of marine macrobenthos: A tool for monitoring pollution-induced disturbance along 
Uran coast, Navi Mumbai. Advances in Environmental Biology, 11(10), 32-52.

Peng S, Zhou R, Qin X, Shi H, and Ding D. 2013. Application of macrobenthos functional groups to estimate the ecosystem health in a semi-enclosed bay. Marine pollution bulletin, 74(1), 302-310.

Putra H, Izmiarti, and Afrizal. 2014. Komunitas Makrozoobentos di Sungai Batang Ombilin Sumatera Barat. Jurnal Biologi UNAND, 3(3), 175-182.

Sabater S, Bregoli F, Acuña V, Barceló D, Elosegi A, Ginebreda A, and Ferreira V. 2018. Effects of human-driven water stress on river ecosystems: a meta-analysis. Scientific Reports, 8(1), 1-11.

Sharma KK and Chowdhary S. 2011. Macroinvertebrate assemblages as biological indicators of pollution in a Central Himalayan River, Tawi (J\&K). International Journal of Biodiversity and Conservation, 3(5), 167-174.

Sharma KK, Langer S, and Sharma R. 2011. Water quality and macrobenthic invertebrate fauna of Behlol Nullah, Jammu (J\&K). The Ecoscan, 5(3\&4), 111-115.

Siahaan R, Indrawan A, Soedharma D, and Prasetyo LB. 2012. Keanekaragaman Makrozoobentos sebagai Indikator Kualitas Air Sungai Cisadane, Jawa Barat-Banten (Macrozoobenthos diversity as indicator of water quality of Cisadane River). Jurnal Bios Logos, 2(1), 1-9.
Tszydel M, Markowski M, Majecki J, Błońska D, and Zieliński M. 2015. Assessment of water quality in urban streams based on larvae of Hydropsyche angustipennis (Insecta, Trichoptera). Environmental Science and Pollution Research 22(19), 14687-14701.

Ulfa M, Julyantoro PGS, and Sari AHW. 2018. Keterkaitan komunitas makrozoobentos dengan kualitas air dan substrat di ekosistem mangrove Taman Hutan Raya Ngurah Rai Bali. Journal of Marine and Aquatic Science, 4(2), 179-190.

Weerman EJ, Herman PM, and Van de Koppel J. 2011. Macrobenthos abundance and distribution on a spatially patterned intertidal flat. Marine ecology progress series, 440, 95-103.

Welch PS. 1948. Limnology $2^{\text {nd }}$ Edition. Macgraw Hill Company, New York.

Wilhm J and Dorris TC. 1966. Species diversity of benthic macroinvertebrates in a stream receiving domestic and oil refinery effluents. American Midland Naturalist, 76, 427-449.

Zawiejska J, Wyżga B, Hajdukiewicz H, Mikuś P, Oglęcki P, Radecki-Pawlik A, and Skalski T. 2016. What improvement does a river need? New insight about the application of invertebrate based index in river health assessment. Rivers, 1-3. 